\title{
COLLECTIVE ACTION THEORY OF MANCUR OLSON ON THE EXAMPLE OF INTEGRATED FRUIT AND VEGETABLE PRODUCERS
}

\author{
Maryla Bieniek-Majka, $\mathrm{PhD}^{1 *}$ \\ Institute of Economic Sciences, Kujawy and Pomorze University in Bydgoszcz \\ *https://orcid.org/0000-0003-1448-7406
}

\begin{abstract}
The aim of this article was to answer the question - do integrated fruit and vegetable producers act in accordance with the assumptions of "the logic of collective actions" by Olson, or want to increase the market organisation level, as suggested by Docian Ciolos, increasing the number of existing groups/organisations? Basing on a library query, the assumptions of the "logic of collective actions" are presented. Using the data provided by the European Commission, a significant negative relationship was found between the average size of the group/organisation and its effectiveness. In addition, there was a regress of organising the fruit and vegetable market in the European Union. Therefore, it is suggested that according to the assumptions of Mancur Olson's theory, selective stimuli (institutional support) motivating members of groups/organisations to produce a common good that can be, i.a., overcoming the barrier of production scale or competitiveness of the sector should be applied.
\end{abstract}

Key words: fruit-vegetable producers' groups/organisations, group activity, free-rider JEL codes: Q13, P32

\section{INTRODUCTION}

Collective action is an activity undertaken by various size groups of entities, people or organisations, connected by a common goal, which in this way can be more easily achieved than in the case of individual actions (Grodzicki, 2015). Promoting the idea of collective action is to eliminate the effects of market imperfections as a mechanism to optimize the allocation of resources and the distribution of income, and to justify state intervention in economy. However, according to Sadłowski (2018), the unreliability of the state in these activities prompts reflection. In his opinion, the imperfection of the market in a given area is not a sufficient condition for intervention.
Supporters of state intervention in agriculture point to a number of reasons that should prompt governments to take corrective actions and recommend the use of specific agricultural policy instruments. On the other hand, opponents of the statist approach question both the premises of intervention and the possibility of achieving the assumed goals with the help of remedies proposed by interventionists.

One of the intervention instruments is a program supporting the organisation of the fruit and vegetable market. Over the years, it has been modified, and the assessment of its effectiveness is not unambiguous. Undoubtedly, in the countries of the so-called new union, the program was an accelerator of integration activities. The wide stream of co-financing resulted

${ }^{1}$ Corresponding author: Toruńska 55-57, 85-023 Bydgoszcz, Poland, m.bieniek-majka@kpsw.edu.pl, +48 663003403 
in increased interest in collective activities of producers. However, the short period of its validity caused this process to be stopped. A drop in the number of producer groups/organisations is noticeable in almost every EU country. So the question arises - is the suggestion made by Ciolos that the organisation of the market should be developed by increasing the number of existing groups, and not by establishing new organisations, correct? Searching for the answer, the author relied on the considerations of "the father of the theory" of collective action - Mancur Olson. His "Logic" makes the matter intuitively obvious: the greater the number of people or companies that could benefit from the collective good, the smaller the share of profits from acting in the group interest that will be charged to the person or company that takes action. Thus, in the absence of selective incentives, the motivation for collective action decreases as the size of the group increases, so that large groups are less able to act in the common interest than the small ones (Congleton, 2015).

\section{THEORETICAL BASIS}

In the sphere of sociology and political sciences, Olson was the first one to draw attention to the contradiction between individual rationality and collective rationality, which prevails on every group undertaking. He did, however, approach the matter as an economist. From economics, he borrowed assumptions about the nature of man as a rational and driven by his self-interest homo oeconomicus, a technique of analysis based on the calculation of marginal costs and benefits and the theory of public goods, which turns out to have many points in common with the theory of groups and organisations. Using these tools, Olson came to completely different conclusions about the functioning of groups than traditional sociology. He questioned the view that groups organise themselves and interact in their own interest in a natural way, guided by some "social instinct" because it is "functional". On the contrary, he said that while there are no mechanisms forcing members of a group to promote a common interest, rational individuals will not take action on its behalf. The theory shows that most organisations produce what economists call a public good, that is, goods or services available to each member, regardless of whether they have borne costs associated with their delivery or not. In the opinion of Olson, if an unorganized group can secure a certain amount of public good, it is only thanks to the fact that it will be provided by the person who cares about that most. All other members of the group will use public goods for free.

His second thesis was about the relationship between the size of the group and its ability to secure public goods. Olson claimed that while a small group can be "privileged", large groups are always "hidden". In his opinion, in groups small enough, it is possible to create a certain suboptimal amount of public good through the voluntary involvement of individual members. In large groups, however, there are no economic incentives to create, by independent members, any amount of public good. Therefore, in small groups, acting for the common interest is possible without the so-called selective stimuli, while in large ones, such additional stimuli are necessary (Ostrowski, 2012).

However, as noted by Grzybek (2016), Olson created a model in which the individual rationality of individuals leads to a situation in which the public good will not be created due to the problem of the freeriding. The possibility of using the common good without bearing the costs of its creation creates the temptation of passive expectations. Rational consumers will choose this attitude (free-riding), and thus as a result the common good will not be delivered at all. According to Olson, there is a clear difference in coping with the problem of free-riders between large and small groups. Small groups will overcome it relatively easily, as the costs of cooperation are low and the participants' control options are significant. Large groups are unlikely to form effective coalitions without having the opportunity to involve potential members in participation. It is noted that at the level of group interests, there is a tendency to achieve the objectives of small groups by neglecting the needs of larger communities. The actions of individuals in favour of the group often conflict with their individual interests, and the short-term, own benefits of group members constitute a barrier to achieve a common goal in the longer term (Grodzicki, 2015). 
The conviction that groups of people with common interests tend to support common goals is unjustified. Even if the group can be very much involved in the implementation of common goals, in most cases it can cease before the optimal level for the members of the group as a whole is reached. So the question arises - is there one goal that would generally characterize the whole organisation? Researchers analysing this problem (De Bruycker, Berkhout and Hanegraaff, 2018) argue that those who belong to an organisation have a common goal (interest), but of course they also often have their own individual goals, differing from others in the organisation. In large groups, subgroups may be created that often have separate interests different from those in the group. Olson (1971) notes that organisations that do not serve the interests of their members are nothing new. Festinger pointed out that "the attractiveness of group membership is not that farmers would be more inclined to themselves if they could achieve 'something' thanks to this membership". This was confirmed by Laski, claiming that the associations strive to meet the goals of the organisation, which are created on the basis of individual needs of people having something in common, they are to serve the interests of their members. Of course, there is no sense in the operation of the organisation, if individual, unorganized action can be used to achieve the goals of the individual in the same way, or even more effectively. A single member of a large organisation is in a similar situation as a company in a perfectly competitive market, his own efforts will not have a noticeable impact on the entire organisation, but he can enjoy all benefits resulting from the benefits of others, regardless of whether they have acted for him or not. The problem with a free-rider is easier to be solved in small groups with specific interests than in large groups representing multiple interests.

\section{MATERIALS AND METHODS}

Ciolos claimed that the development of fruit and vegetable market organisation could be based on adding new members to the already existing groups, and not necessarily on establishing new organisations. Confronting this opinion against the theory of collective action by Olson, the author of this work wanted to try to answer the question which approach can be noticed among integrated fruit and vegetable producers in the EU. Based on a library query and the data from annual reports of EU member states regarding the functioning of groups and organisations of fruit and vegetable producers between 2012-2016, made available by the European Commission, the correlation between the average size of groups/organisations and their effectiveness (measured by the average value of sales) in individual countries has been measured.

\section{RESULTS AND DISCUSSION}

According to Chaddada and Cook (2004) quick and fundamental structural changes taking place in the global food system caused by industrialisation expose agricultural producers to increased domestic and international competition. These changes suggest that it is important to consider whether organisational structures that have evolved in the past will be appropriate in the future. The success of groups/organisations in response to the challenges resulting from the industrialisation of agriculture will probably depend on both the competitive strategy and the organisational structure. It is important that the leaders of these organisations, considering the organisational changes, remember that the decision depends on the fundamental orientation of the owners/producers. Hart notes (2003) that Olson's hypothesis, in its strongest form, indicates that it is more likely that highly focused industries will be represented in the policy making process than those less concentrated. Agriculture, which has many producers is characterized by significant barriers to collective actions. Identifying the beneficiaries and directing effective public policy instruments that would convince them that there is a sufficient number of them, that in the absence of selective incentives, it is expensive. It is said that in such conditions "free riding" on the efforts of others is very likely. Farmers, like other dispersed social groups, will usually be "hidden", which means they have a common political interest, but it remains unrepresented. According to Ząbkowicz (2016), a member of the group/organisation makes decisions primarily for the sake of self-interest. Because people 
do not have access to all the necessary and important information or have uneven access, their calculations do not always give the optimal effect. "Calculation" rationality is limited by information asymmetry. Individuals, comparing the benefits and costs of achieving their own preferences, take into account expectations regarding the behaviour of other people. In addition to economic effects, they are driven by the desire to achieve social and psychological goals, such as gaining prestige, respect, friendship, etc. Bringing the interest to material benefits, therefore, seems to be a simplification that has been outgrown in economics. Individual interest, at least from the point of view of modern institutionalism, consists of achieving one's own preferences to a satisfactory degree, but also of avoiding condemnation or gaining recognition, which come from social networks.

Some organisations, due to their ignorance, may neglect the cooperation of their members. The existence of formal or informal groups is obvious, because it results from the basic tendency to instinctive joining as, according to Olson (1971), following Mosca, in the name of "fighting together with another herd". Large fragmentation of agricultural holdings and the progressive consolidation of the processing industry and the growing importance of super- and hypermarket chains, mean that the terms of contracts concluded by small farms with processing plants or large retail chains are often imposed by the other party. Farmers are then unable to gain sufficient profits allowing them to function on the market. The factor influencing the bargaining power of entities is the amount of resources held, and the ability to adapt them to the changing market conditions. Cooperation may increase the bargaining power of agricultural producers through the impact on the market structure (in the case of creation of formal producer groups), the size of economic resources (through joint investments or the joint use of resources, such as agricultural machinery) and reducing transaction costs (e.g. by joint use of means of transport). However, as studies conducted in Poland indicate, traditional forms of cooperation characterising small farmers help them only to survive. Only more advanced forms of cooperation - like participation in producer groups - constitute a development strategy. It is worth noting that the level of organisation of farmers in the countries of Central and Eastern Europe is unfortunately rather low. Partial explanation of this phenomenon refers to negative experiences from the period of collective agriculture in the communist period, however, market and political factors cannot be neglected either (Mielczarek-Andrzejewska, 2012).

One of the political incentives to overcome the barrier of the scale of supply in agriculture was a program supporting horizontal links of entities and their joint activities within economic organisations, which according to Nosecka (2017), allowed to broaden the scope of instruments of competing agricultural entities for marketing activities, logistic and quality ensuring the fulfilment of market requirements. Nosecka (2017) also notes that Polish gardeners were the largest beneficiary of this EU program because they absorbed $95 \%$ of the total support paid to these units. Despite the fact that the program supporting integration activities among gardeners inspired them to establish groups and organisations of fruit and vegetable producers thanks to its size, observing their durability on the market, it should be stated that it was too short. For example, in Poland, the register kept by the President of ARMA shows that 344 entities have been established since the beginning of the program, and at the end of 2018 there were only 272 , which means that this number decreased by almost 21\%. In the Czech Republic and Slovakia, 305 producer groups received support. Many of the supported units are no longer active. In these countries, only over twenty organisations still operate, but they do not have a significant impact on the increase in the added value of the agricultural sector (Kotyza et al., 2018). In Slovakia, we also note that reducing the number of groups by $40 \%$ resulted in a decrease in the number of associated members by $49 \%$. Only Romanian gardeners in 2012-2016 showed increased interest in cooperation, the number of associated members increased almost fourfold, while the number of groups/organisations increased by only $60 \%$. A different situation was noted in Italy, where the number of organisations increased by $8 \%$, but the number of integrated members decreased by $30 \%$. In the figure below, we see that as the average number of members in the group/organisation increases, the average 


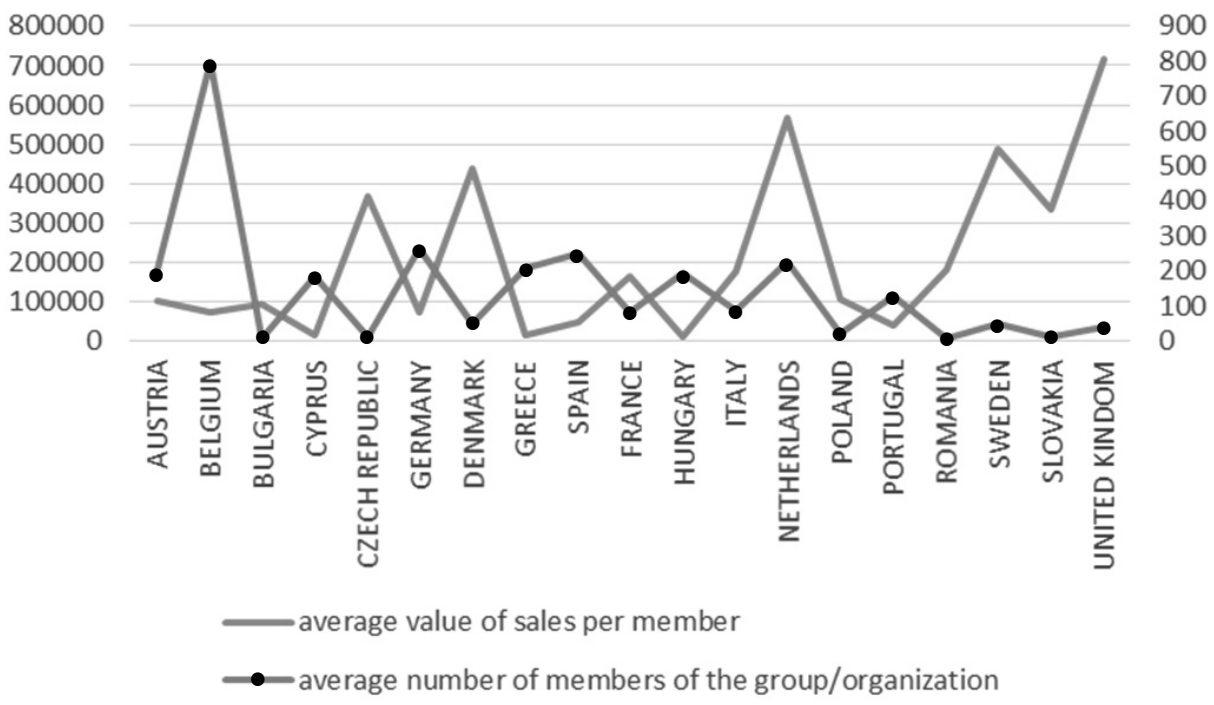

Figure 1. Average number of members of fruit and vegetable producer groups and organisations in the EU and average value of per capita sales in 2012-2016

Source: own study based on annual reports sent by the countries to the European Commission.

sales per capita decreases. Correlation between these variables is significant, negative $(-0.34)$, which confirms that larger groups are characterised by lower efficiency of operation.

Other studies, although much more limited, as carried out in Poland, in Kujawsko-Pomorskie Voivodeship, where about $15 \%$ of Polish fruit/vegetable producer groups/organisations operates, also confirm greater efficiency of smaller groups, as the relationship indicated by logit regression showed that the decrease in the number of group members increased by $10 \%$ the chances of obtaining a competitive advantage (Bieniek-Majka and Matuszczak, 2017).

\section{SUMMARY}

Observing the changes in the organisation of the fruit and vegetable market in the European Union, it seems that the logic of functioning of groups by Olson finds its justification. The observed fact of a faster rate of decrease in the number of associated members than the number of groups and organizations, proves the regression of market organisation and is the opposite of the theory of positive effects resulting from synergy and scale. It can also be suggested that most entities were established due to the selective stimulus which was the relative ease of obtaining funds. Establishing selective incentives (institutional support) motivating to organize, is in itself a collective good (Grodzicki, 2015), that is, according to theory, it should be delivered continuously, not temporarily, because it causes the cessation of joint action as the example of Poland or the Czech Republic as well as other countries, with the exception of Romanian gardeners, has shown. Especially because gardening is very much exposed to agrometeorological factors, it should be covered by long-term interventionism, which allows for levelling fluctuations resulting from factors independent of gardeners. It would be advisable to continue the support (spread over time) to create conditions for the further organisation of the fruit and vegetable market, since its level, especially in the countries of Central and Eastern Europe, is insufficient, which reduces the competitiveness of gardeners on the international arena. This is also confirmed by Nosecka (2017), indicating that without external support and creating financial incentives, it is unlikely that the process of overcoming the barrier of the scale of production in farms will be faster by creating larger economic organisms - producer groups and organisations. 


\section{REFERENCES}

1. Bieniek-Majka, M., Matuszczak, A. (2017). Integracja pozioma na rynku owoców i warzyw na przykładzie województwa kujawsko-pomorskiego [Horizontal integration of the fruit and vegetables market in kujawsko-pomorskie voivodeship]. Wydawnictwo KPSW w Bydgoszczy, Bydgoszcz.

2. Chaddad, F.R., Cook, M.L. (2004). Understanding New Cooperative Models: An Ownership-Control Rights Typology. Review of Agricultural Economics, 26 (3), pp. 348-360.

3. Congleton, R.D. (2015). The Logic of Collective Action and Beyond. Working Paper 15-23. Retrieved from: https://business.wvu.edu/files/d/105d5d54-2ca3-4a50bbf6-7d80ab708d08/15-23.pdf [Accessed 12.02.2019].

4. De Bruycker, I., Berkhout, J., Hanegraaff, M. (2018). The paradox of collective action: Linking interest aggregation and interest articulation in EU Legislative Lobbying. Governance, 32 (2), pp. 295-312, https://doi. org/10.1111/gove.12373

5. Grodzicki, M. (2015). Dlaczego grupom udaje się podejmować działania? Przedstawienie teorii działań zbiorowych Elinor Ostrom [Why do groups manage to take action? Presentation of the Elinor Ostrom's theory of collective actions]. Ekonomia Społeczna, 1, pp. 66-78 .

6. Grzybek, D. (2016). Przeciw tezom o niemożności - Elinor Ostrom o działaniu zbiorowym i zarządzaniu wspólnymi zasobami [Against the theses on inability - Elinor Ostrom on collective actions and management of common resources]. International Journal of Contemporary Management, 11 (1), pp. 104-112.
7. Hart, D.M. (2003). Political Representation in Concentrated Industries: Revisiting the 'Olsonian Hypothesis'. Business and Politics, 5, pp. 261-286.

8. Kotyza, P., Tomsik K., Elisova, K., Hornowski, A. (2018). Supporting Producer Groups - Increasing Producer's Value Added? Scientia Agriculturae Bohemica, 49 (2), pp. 142-152.

9. Milczarek-Andrzejewska, D. (2012). Drobne gospodarstwa rolne we współczesnych łańcuchach żywnościowych [Participation of small farms in modern food supply chains]. Problemy Drobnych Gospodarstw Rolnych, 1, pp. 95-113.

10. Nosecka, B. (2017). Czynniki i mierniki konkurencyjności zewnętrznej sektora ogrodniczego i jego produktów [Factors and measures of external competitiveness of the horticultural sector and its products]. IERiGŻ-PIB, Warszawa.

11. Olson, M. (1971). The logic of collective action. Public Goods and the Theory of Groups. Harvard University Press, Cambridge MA, London.

12. Ostrowski, Ł. (2012). Recenzja książki Mancura Olsona „Logika działania zbiorowego. Dobra publiczne i teoria grup" [Review of Mancur Olson book "Logic of collective activities. Public goods and theory of groups"]. Decyzje, 18, pp. 117-121.

13. Sadłowski, A. (2018). Przyczyny i ograniczenia interwencjonizmu państwowego w rolnictwie [Causes and limitations of state intervention in agriculture] Zeszyty Naukowe PWSZ w Płocku. Nauki Ekonomiczne, 27, pp. $167-$ -185, https://www.doi.org/10.19251/ne/2018.27(11)

14. Ząbkowicz, A. (2016). Jak rozumiany jest interes w ekonomii? [How we understand the interest in the economy?]. Studia i Prace WNEiZ US, 44 (2), pp. 399-407. 